\title{
EVALUATION OF THE IMPACT OF ETHANOL ON THE NERVOUS CONTROL OF MICTURITION - THE ANALYSIS OF THE LINK BET WEEN THE CONCENTRATION OF ALCOHOL IN THE BLOOD AND THE VOLUME OF URINE IN THE BLADDER
}

Anna Salwa, Justyna Pieczątka, Olga Kucharczyk

From the Student Scientific Group of the Forensic Medicine Department of Jagiellonian University Medical College, Poland Head of Department: Prof Dr hab. M. Kłys Student Scientific Group Tutor: Dr Tomasz Konopka

\section{EVALUACIJA UTICAJA ETANOLA NA NERVNU KONTROLI MOIRENJA -ANALIZA VEZE IZMEĐU KONCENTRACIJE ALKOHOLA U KRVI I ZAPREMINE MOKRAĆE U MOKRAĆNOJ BEŠICI \\ Anna Salwa, Justyna Pieczątka, Olga Kucharczyk \\ Studentska naučna grupa Odseka za forenzičnu medicinu "Jagiellonian” Medicinskog univerziteta, Poljska Rukovodilac odseka: Prof .dr M. Kłys}

Mentor studentske naučne grupe: dr Tomasz Konopka

Received / Primljen: 22.06.2012.

Accepted / Prihvaćen: 12.08.2013.

\begin{abstract}
Numerous biochemical and electrophysiological studies have determined that the functions of certain receptors and ion channels for which the are in some way affected by ethanol . Some of these are involved in the neural control of micturition, and it is therefore possible that ethanol induces urinary retention. The aim of this study was to analyse the relationship between the concentration of alcohol in the blood and the volume of urine in the bladder measured during autopsy. The study was based on autopsy protocol data from 702 people. The inclusion criteria were age not exceeding 50 years and a blood alcohol level of at least 0.5 parts per thousand. A correlation between the blood alcohol concentration and a bladder urine volume over $200 \mathrm{ml}$ can be portrayed as part of a range limited by curves asymptotically converging at a value of 3 per mil. This phenomenon may be explained by the effect that alcohol has on receptors involved in the micturition reflex, which should typically be engaged at approximately $200 \mathrm{ml}$ of urine in the bladder. The lower limit of this range can be explained by GABA-A stimulation as well as the inhibition of NMDA receptors or by decreasing influx through calcium channels. Both of these effects inhibit the micturition reflex. However, the upper limit, which indicates reduced urine retention, may be caused by the action of high concentrations of ethanol at the ends of the adrenergic fibres, causing their dysfunction, or by changes in the intracellular calcium ion concentration.
\end{abstract}

Key words: Alcohols, Bladder, Ethanol, Urine

\section{SAŽETAK}

Brojne biohemijske i elektrofiziološke studije su utvrdile da su funkcije određenih receptora $i$ jonskih kanala, na neki način, pogodene dejstvom etanola. Neki od njih su uključeni u nervnu kontrolu mokrenja, i zato je moguće da etanol izaziva retenciju urina. Cilj ove studije bio je da analizira odnos izmedu koncentracije alkohola u krvi i zapremine urina u mokraćnoj bešici, merenih prilikom obdukcije. Studija je zasnovana na podacima iz obducionih protokola 702 ljudi. Kriterijumi za uključivanje su bili starost ispod 50 godina $i$ količina alkohola u krvi najmanje 0,5 promila. Korelacija izmedu koncentracije alkohola u krvi i zapremine urina u mokraćnoj bešici preko $200 \mathrm{ml}$ može biti predstavljena kao deo opsega ograničenog krivama koje asimptotski konvergiraju ka vrednosti 3 promila. Ovajfenomen se može objasniti efektom koji alkohol ima na receptore koji su uključeni u refleks mokrenja, koji se obično aktiviraju pri zapremini od oko 200 ml mokraće u mokraćnoj bešici. Donja granica tog opsega se može objasniti stimulacijom GABA-A receptora kao i inhibicijom NMDA receptora, ili smanjenjem influksa kroz kanale za kalcijum. Oba ova efekta inhibišu refleks mokrenja. Medutim, gornja granica, koja ukazuje na smanjenu retenciju urina, nastaje dejstvom visokih koncentracija etanola na završetke adrenergičkih vlakana, izazivajući njiho$v u$ disfunkciju, ili promene $u$ intracelularnoj koncentraciji jona kalcijuma.

Ključne reči: alkoholi, mokraćna bešika, etanol, urin 


\section{INTRODUCTION}

Several case reports linking ethanol and urinary bladder dysfunction with resulting urinary retention have been published. [1,2] Animal studies using the urinary bladders of rabbits have demonstrated that ethanol increases bladder capacity and decreases detrusor muscle contraction activity. However, the mechanism regulating this phenomenon is unclear. [16] Opinions differ as to whether this is controlled by the effect of an increased intracellular calcium level, nitric oxide synthesis inhibition or the regulation of receptor function. $[3,4,6]$

Ethanol influences the functioning of receptors involved in the regulation of reflex micturition. GABA-A receptors inhibit the voiding reflex, whereas the NMDA receptors activate it. The influence of the autonomic nervous system is also important. Parasympathetic postganglionic axons in the pelvic nerve release acetylcholine (Ach), which results in bladder contraction by stimulating M3 muscarinic receptors in the bladder smooth muscle. However, sympathetic postganglionic neurons release noradrenaline (NA), which activates beta- 3 adrenergic receptors to relax the bladder smooth muscle and alfa-1 adrenergic receptors to contract the urethral smooth muscle. [3]

\section{MATERIALS AND METHODS}

The study was performed via a retrospective analysis of autopsy protocols archived at the Forensic Medicine Department of Jagiellonian University Medical College from 2006 to 2010. The study group comprised 702 people younger than 50 years of age with a blood ethanol concentration at or above 0.5 per mill. We limited the age of the decease to a maximum of 50 years to exclude the influence of benign prostatic hyperplasia, which can cause urinary retention. The exclusion criteria also included the presence of drugs and toxic substances such as diazepam, carbamazepine, non-steroidal anti-inflammatory drugs, chlorpromazine, morphine and bencyclane in the blood sample. This action eliminated their influence on the results by causing urinary retention. [1] The statistical analysis was performed using Statistica (Statsoft, v8.0) software.

The statistical analysis was performed for all cases and a group without a history of chronic ethanol abuse. Urine volume was measured in millilitres $(\mathrm{mL})$, and the ethanol blood concentration was per mills (ppm). Descriptive statistical analysis was performed for all cases. Ninety-five per cent confidence intervals $(95 \% \mathrm{CI})$ were also calculated on the basis of the Poisson distribution. The distributions of the blood alcohol concentration and bladder urine volume were checked for normality with the use of the Shapiro-Wilk test. If P values were less than 0.01 , there was no normality. However, when a data set is larger than 100 cases, parametric methods are the most appropriate. Simple linear correlations and linear multiple regression were used for the assessments.

\section{RESULTS}

Table 1. The results of the linear correlation analysis of urine volume in the urinary bladder and blood ethanol concentration in the two groups.

\begin{tabular}{|l|l|l|l|}
\hline $\begin{array}{l}\text { Data analysis } \\
\text { was performed } \\
\text { in the following } \\
\text { groups: }\end{array}$ & $\begin{array}{l}\text { Pearson's } \\
\text { correlation } \\
\text { coefficient }\end{array}$ & $\begin{array}{l}\text { The coefficient } \\
\text { of determination } \\
\left(\mathrm{R}^{2}\right)\end{array}$ & $\begin{array}{l}\text { Level of } \\
\text { significance } \\
(\mathrm{p} \text {-value })\end{array}$ \\
\hline $\begin{array}{l}\text { All cases } \\
(\mathrm{n}=702)\end{array}$ & 0.20 & 0.04 & 0.00001 \\
\hline $\begin{array}{l}\text { Cases without } \\
\text { alcoholics } \\
(\mathrm{n}=473)\end{array}$ & 0.18 & 0.03 & 0.00007 \\
\hline
\end{tabular}

The coefficient of determination showed the degree of fit of our model to a model with linear correlations between variables. According to the low level of correlation, which was $3-4 \%$, there was no statistically significant linear correlation.

\begin{tabular}{|c|c|c|}
\hline $\begin{array}{l}\text { Analysed relationship to the vari- } \\
\text { able: volume of urine in the bladder }\end{array}$ & $\begin{array}{l}\text { All cases } \\
(\mathrm{n}=702)\end{array}$ & $\begin{array}{l}\text { Cases without } \\
\text { alcoholics } \\
(\mathrm{n}=473)\end{array}$ \\
\hline blood alcohol level ${ }^{2}$ & $\begin{array}{l}\text { Beta }=0.19 \\
\mathrm{R}^{2}=0.03 \\
\mathrm{p}=0.00002\end{array}$ & $\begin{array}{l}\text { Beta }=0.16 \\
\mathrm{R}^{2}=0.02 \\
\mathrm{p}=0.0001\end{array}$ \\
\hline blood alcohol level $^{3}$ & $\begin{array}{l}\text { Beta }=0.17 \\
\mathrm{R}^{2}=0.03 \\
\mathrm{p}=0.00007\end{array}$ & $\begin{array}{l}\text { Beta }=0.12 \\
\mathrm{R}^{2}=0.01 \\
\mathrm{p}=0.004\end{array}$ \\
\hline sqrt(blood alcohol level) & $\begin{array}{l}\text { Beta }=0.2 \\
\mathrm{R}^{2}=0.04 \\
\mathrm{p}=0.00001\end{array}$ & $\begin{array}{l}\text { Beta }=0.18 \\
\mathrm{R}^{2}=0.03 \\
\mathrm{p}=0.00005\end{array}$ \\
\hline $\log$ (blood alcohol level) & $\begin{array}{l}\text { Beta }=0.19 \\
\mathrm{R}^{2}=0.04 \\
\mathrm{p}=0.00001\end{array}$ & $\begin{array}{l}\text { Beta }=0.2 \\
\mathrm{R}^{2}=0.04 \\
\mathrm{p}=0.00002\end{array}$ \\
\hline $\mathrm{e}^{\text {blood alcohol level }}$ & $\begin{array}{l}\text { Beta }=-0.01 \\
R^{2}=0.006 \\
p=0.9\end{array}$ & $\begin{array}{l}\text { Beta }=0.002 \\
R^{2}=0.0006 \\
p=0.8\end{array}$ \\
\hline
\end{tabular}

Table 2. The results of a linearised linear regression of urine volume in the urinary bladder and blood ethanol concentration with the analysed factors.

When we considered the coefficients of determination, no nonlinear model could be described by any function that could explain this correlation.

A scatterplot of correlations between blood ethanol concentration and urine volume in the urinary bladder was made to investigate more advanced correlations.

In cases with a urine volume above $200 \mathrm{ml}$, we observed that dispersion of the blood ethanol concentration decreased. The scatterplot of correlations between blood ethanol concentration and urine volume in the urinary bladder could be limited by asymptotic curves convergent at a blood ethanol concentration of 3 per mills. This correlation was more noticeable in cases without a history of chronic alcohol abuse. 
A scatterplot (all cases from the database): blood alcohol level compared to the volume of urine in the bladder

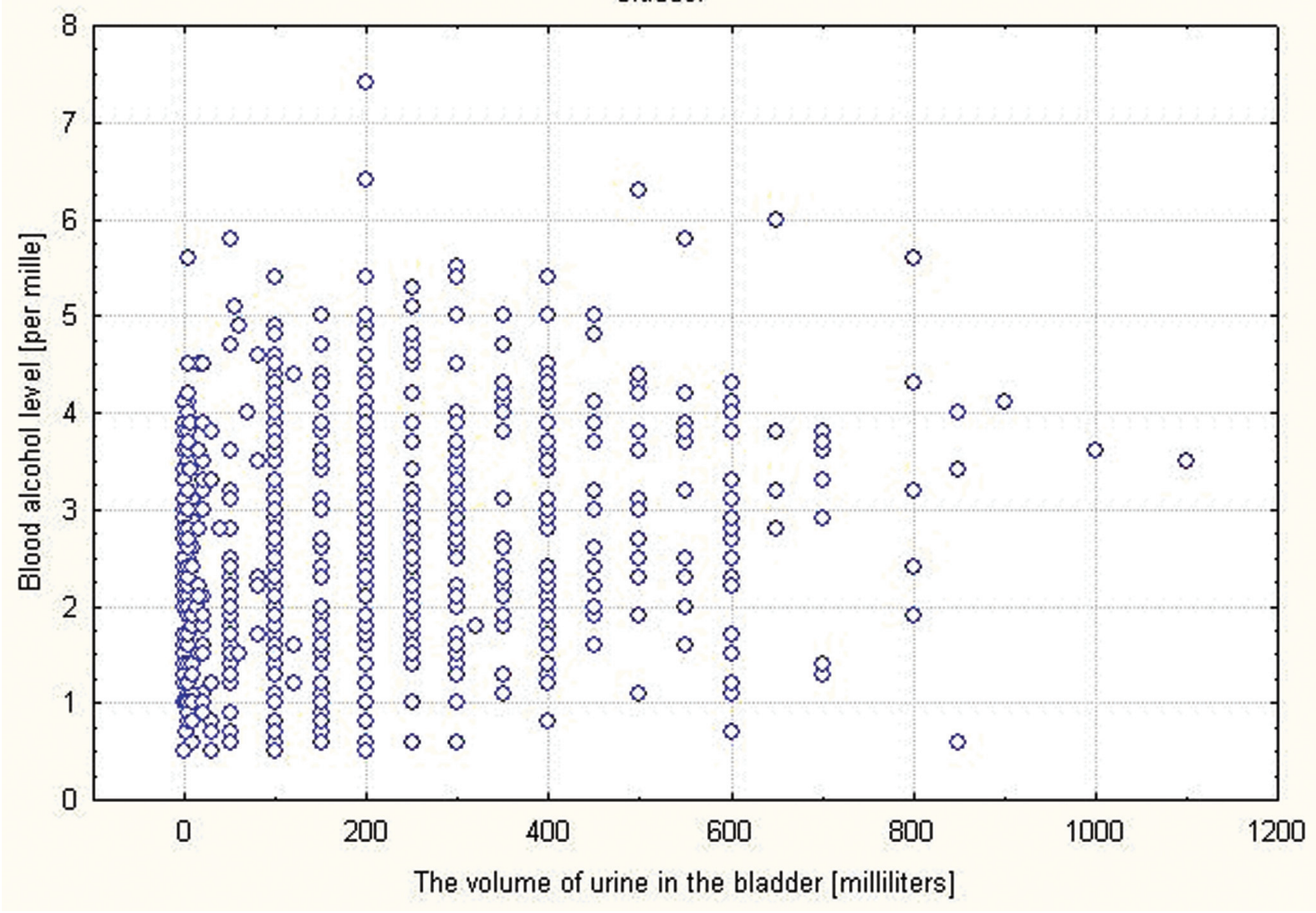

Figure 1. Figure showing the relation between urine volume in the urinary bladder and blood ethanol

A scatterplot (people without a history of chronic alcohol abuse): blood alcohol level compared to the volume of urine in the bladder

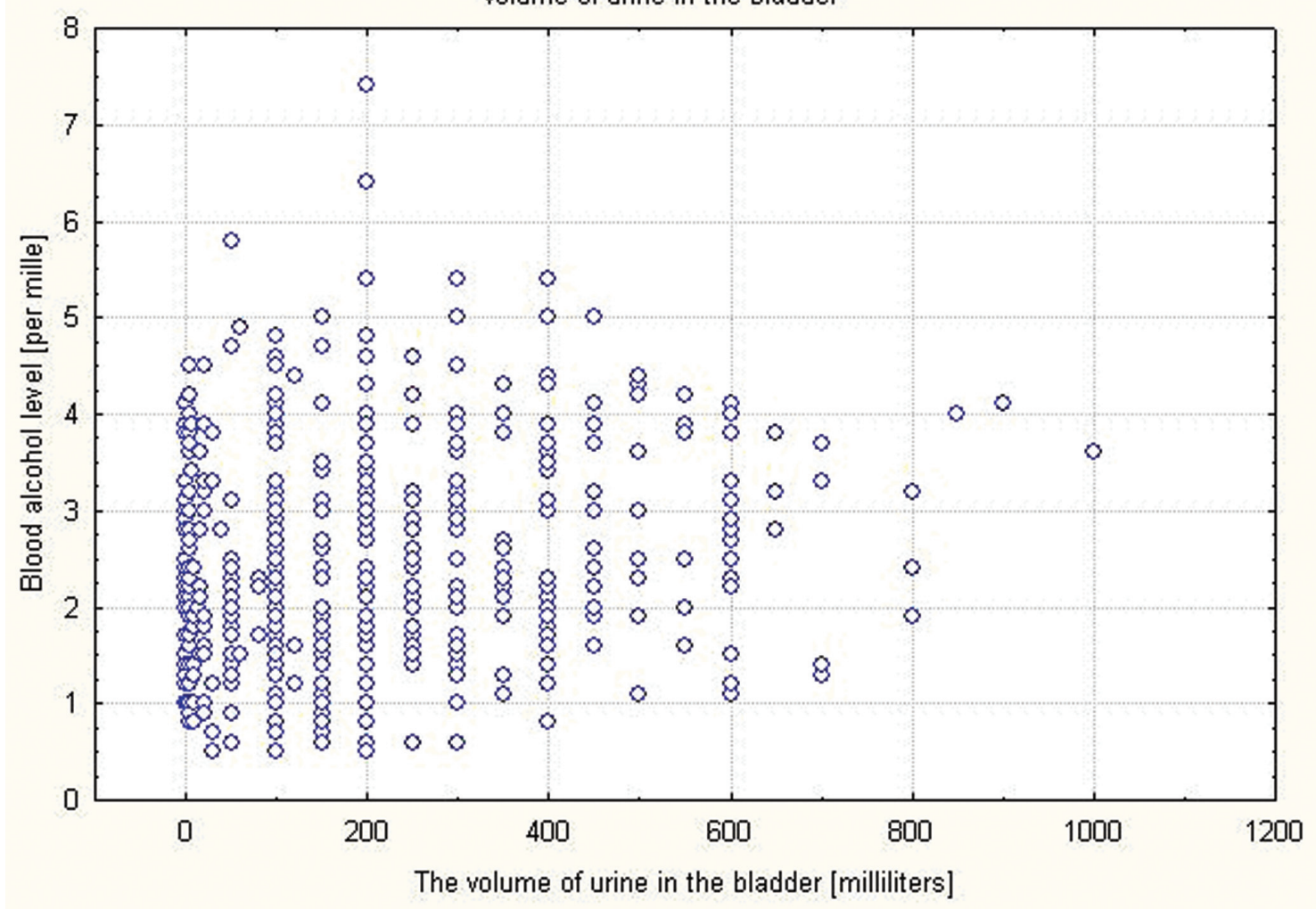

Figure 2. Relation of urine volume in the urinary bladder and blood ethanol concentration in the group without a history of chronic ethanol abuse. 
A scatterplot (people without a history of chronic alcohol abuse): blood alcohol level compared to the volume of urine in the bladder

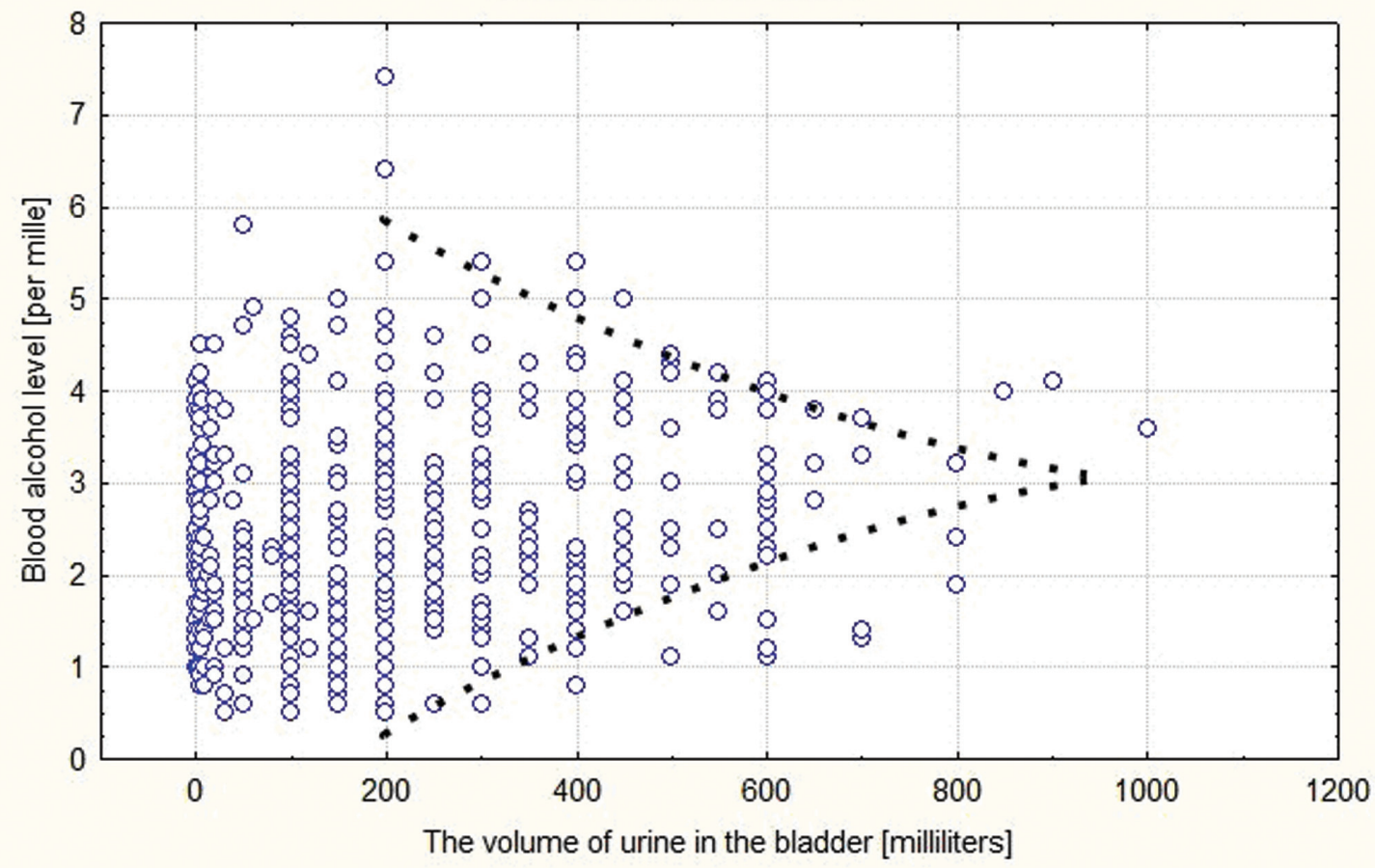

Figure 3. A scatterplot of urine volume in the urinary bladder and blood ethanol concentration with asymptotic limiting curves (cases without a history of chronic ethanol abuse).

As shown in figure 3, limitation curves were created to gain a better visual understanding of our argument.

\section{DISCUSSION}

Molecular pharmacology studies have disclosed a few primary targets for ethanol such as N-methyl-D-aspartate (NMDA ), $\gamma$-aminobutyric acid A (GABA-A), glycine, 5-hydroxytryptamine-3 (5-HT3), neuronal nicotinic acetylcholine $(\mathrm{nACh})$ receptors and $\mathrm{L}$-type $\mathrm{Ca}^{2+}$ channels. $[5,7,8,9]$ Some of these neurotransmitter systems are responsible for the effects of ethanol on urine retention described in our study. Experiments performed on rats by Matsumoto have shown that the intravenous administration of an NMDA receptor antagonist blocks the bladder contractions evoked by electrostimulation of the PMC (pontine micturition centre), supporting the role of NMDA receptors in mediating excitatory transmission in the descending limb of the spinobulbospinal micturition reflex pathway. [18] In the next section, we describe the results of Lovinger's experiment, which confirmed the inhibitory effect of ethanol on NMDA receptors and may explain our findings. In Pehrson's experiment, the blockade of GABA-A and GABA-B receptors in the spinal cord and brain stimulated rat micturition, which confirmed the assumption that activation of GABA-A and GABA-B receptors may be responsible for the continuous inhibition of the micturition reflex within the CNS. [19] The results of studies confirming the stimulating effect of ethanol on GABA receptors and the implications of these findings with respect to our results are described in the next section. The action of ethanol on serotonin receptors cannot be considered because it affects subtype 5-HT3, whereas subtypes 5-HT1 and 5-HT7 are involved in controlling the micturition reflex. Additionally, the impact of ethanol on acetylcholine receptors cannot be considered because although several studies have confirmed its action on nicotinic receptors, its effect on muscarinic receptors remains unclear, and research has focused primarily on chronic abuse. [20,21] Göthert's experiment suggested a relation between the ethanol concentration and noradrenaline output. The noradrenaline output from peripheral sympathetic nerves was inhibited only by lethal concentrations of alcohol. Many studies have shown that noradrenaline causes detrusor muscle relaxation and inhibits adrenergic fibres, resulting in detrusor contraction. [22] The influence of ethanol on ion channels, particularly calcium channels, which subsequently increases the intracellular calcium concentration and may facilitate detrusor muscle constriction, might also be important. [16]

We separately analysed a group with a history of chronic alcohol abuse to investigate neuroadaptation of receptor systems caused by the effects of long-term ethanol use on neurotransmitters. Ethanol tolerance was caused by a decreased number of GABA-A receptors (down-regulation); changes in receptor structure and a decreased response by neurotransmitters; or an increased number of NMDA receptors (up-regulation). [5, 7-12] This adaptation of the receptor system to chronic activation/inhibition could have interfered with our outcomes if the receptor response participates in the effect of ethanol on micturition. 
In our analysis, the described correlation in the group with a urine volume above $200 \mathrm{ml}$ could be explained by the receptor response because micturition is activated by this amount of urine. [4] Moreover, after the exclusion of alcoholics, the scatterplot was more restricted, which could be explained by adaptation of the receptor system.

As shown in Figure 3, the lower limiting curve demonstrated increased urine retention. This could be the effect of micturition reflex inhibition or an inability to contract the detrusor muscle. The research of Lovinger on NMDA receptors in rat ganglions showed that ethanol inhibition was dependent on the ethanol concentration. Increasing inhibition potential was observed from a blood ethanol concentration of 0.12 per mills $(2.5 \mathrm{mM}$ ) to 2.3 per mills ( 50 $\mathrm{mM}$ ); a further concentration increase had no influence on the strength of receptor inhibition. The IC50 (the concentration that inhibits $50 \%$ of receptors) was 0.46 per mills $(10 \mathrm{mM})$ [8-10]. Stimulated NMDA receptors activate the micturition reflex. Inhibition of NMDA receptors explains the increasing urinary retention observed at a low blood ethanol concentration. We hypothesise that the lower limitation curve at a blood ethanol concentration of 0.5 per mills to 3 per mills was caused by this mechanism. Our research indicates that ethanol activates GABA-A receptors at a blood concentration above 2.76 per mills $(60 \mathrm{mM})$, but receptors containing the delta $(\delta)$ subunit were activated by a blood ethanol concentration of at least 0.14 per mills $(3 \mathrm{mM}) .[5,12]$ The GABA-A receptors that participated in the micturition reflex consisted of $\alpha_{2} \delta$ subunits, and their activation inhibited the micturition reflex and influenced the lower limitation curve. [11] Another explanation of the lower limitation curve could be the influence of ethanol on smooth muscle tension, which is regulated by calcium channels. This leads to decreased intracellular calcium inflow and limits detrusor muscle contraction. A study using PC12 cells showed this effect at ethanol concentrations of 1.15-1.38 per mills (25-30 mM). However, an ethanol concentration above 4.6 per mills $(100 \mathrm{mM})$ increased the free intracellular calcium level. This effect could explain the upper limiting curve, when decreased urinary retention was caused by detrusor muscle contraction. [10, 15] The mechanism through which the calcium level was increased is unclear, but calcium can be released from intracellular depots. $[6,16]$ Ethanol may also cause adrenergic nerve fibres to malfunction, which could influence the upper limiting curve. Laboratory experiments on isolated rat detrusor muscle have shown that ethanol can weaken the beta-adrenergic response upon stimulation. [13] Research on noradrenaline nerve excretion in the presence of ethanol revealed 50\% decreased excretion (IC50) in response to chemical stimulation at an ethanol concentration of 5.6 per mills $(129 \mathrm{mM})$. [14] According to cited research, the inhibition of urine retention as an effect of a high ethanol concentration could be explained by adrenergic system inhibition and dominance of the cholinergic system. [17]

\section{CONCLUSION}

It has been shown that ethyl alcohol affects the micturition reflex and can cause urine retention. Ethanol inhibited the micturition reflex at a blood concentration below 3.0 per mills. Higher ethanol concentrations inhibited urinary retention via inhibition of the adrenergic system and activated the micturition reflex.

A low ethanol concentration affected NMDA receptors, GABA-A receptors and the intracellular calcium level, inhibiting the micturition reflex and leading to urinary retention. A higher ethanol concentration inhibited the adrenergic system and affected the intracellular calcium level, inhibiting urinary retention and facilitating detrusor muscle contraction.

\section{REFERENCES}

1. Selius BA, Subedi R. Urinary retention in adults: diagnosis and initial management. Am Fam Physician. 2008; 77(5):643-50.

2. Iga J, Taniguchi T, Ohmori T. Acute abdominal distension secondary to urinary retention in a patient after alcohol withdrawal. Alcohol Alcohol. 2005; 40(1):86-7.

3. Fowler CJ, Griffiths D, de Groat WC. The neural control of micturition. Nat Rev Neurosci. 2008; 9(6):453-66.

4. Jiang $\mathrm{CH}$, Lindstrom $\mathrm{S}$. Prolonged enhancement of the micturition reflex in the cat by repetitive stimulation of bladder afferents. J Physiol. 1999; 517 ( Pt 2):599-605.

5. Spanagel R. Alcoholism: a systems approach from molecular physiology to addictive behavior. Physiol Rev. 2009; 89(2):649-705.

6. Yokoi K, Ohmura M, Kondo A, Miyake K, Saito M. Effects of ethanol on in vivo cystometry and in vitro whole bladder contractility in the rat. J Urol. 1996; 156(4):1489-91.

7. Sanna E, Harris RA. Recent developments in alcoholism: neuronal ion channels. Recent Dev Alcohol. 1993; 11:169-86.

8. Weight FF, Lovinger DM, White G. Alcohol inhibition of NMDA channel function. Alcohol Alcohol Suppl. 1991; 1:163-9.

9. Lovinger DM, White G, Weight FF. Ethanol inhibition of neuronal glutamate receptor function. Ann Med. 1990; 22(4):247-52.

10. Weight FF. Cellular and Molecular Physiology of Alcohol Actions in the Nervous System. In: Smythies JR, Bradley RJ. International review of neurobiology. / Volume 33. San Diego: Academic Press, 1992: 289-348

11. Fleming RL, Wilson WA, Swartzwelder HS. Magnitude and ethanol sensitivity of tonic GABAA receptor-mediated inhibition in dentate gyrus changes from adolescence to adulthood. J Neurophysiol. 2007; 97(5):3806-11.

12. Akk G, Steinbach JH. Low doses of ethanol and a neuroactive steroid positively interact to modulate rat $\mathrm{GABA}(\mathrm{A})$ receptor function. J Physiol. 2003; 546(Pt 3):641-6. 
13. Göthert M, Thielecke G. Inhibition by ethanol of noradrenaline output from peripheral sympathetic nerves: possible interaction of ethanol with neuronal receptors. Eur J Pharmacol. 1976; 37(2):321-8.

14. Utkan T, Erden F, Yildiz F, Ozdemirci S, Ulak G, Gacar MN. Chronic ethanol consumption impairs adrenoceptor- and purinoceptor-mediated relaxations of isolated rat detrusor smooth muscle. BJU Int. 2001; 88(3):278-83.

15. Rabe CS, Weight FF. Ethanol's effects on neurotransmitter release and intracellular free calcium in PC12 cells. Adv Alcohol Subst Abuse. 1988; 7(3-4):95-7.

16. Ohmura M, Kondo A, Saito M. Effects of ethanol on responses of isolated rabbit urinary bladder and urethra. Int J Urol. 1997; 4(3):295-9.

17. Yoshimura N. Bladder afferent pathway and spinal cord injury: possible mechanisms inducing hyperreflexia of the urinary bladder. Prog Neurobiol. 1999; 57(6):583-606.
18. Matsumoto G, Hisamitsu T, de Groat WC. Role of glutamate and NMDA receptors in the descending limb of the spinobulbospinal micturition reflex pathway of the rat. Neurosci Lett 1995; 183:58 - 61.

19. Pehrson R, Andersson K-E. Effects of tiagabine, a gamma-aminobutyric acid re-uptake inhibitor, on normal rat bladder function. J Urol 2002; 167:2241-2246.

20. Costa LG, Guizzetti M. Muscarinic cholinergic receptor signal transduction as a potential target for the developmental neurotoxicity of ethanol. Biochem Pharmacol. 1999; 57(7):721-6.

21. Caron M, Larsson C, Alling C. Chronic effects of ethanol on muscarinic acetylcholine receptors are modulated by protein kinase C. Addict Biol. 1999; 4(2):163-8.

22. Kondo A. Response of urinary bladder to cholinergic and adrenergic agents. Nagoya Journal of Medical Science 1977; 39(1-2): 37-4 